\title{
Tributes to Dr. W. C. McCalla
}

by E. H. Moss, Edmonton

WILLIAM COPELAND McCALLA, who died in his 90th year, August 22, 1962, at Calgary, was born at St. Catherines, Ontario. As a young man he devoted several years to fruit-growing in the Niagara Peninsula. His botanical explorations began as early as 1895. It was in 1899 that he made his first collecting expedition to the west, visiting Banff at that time, and discovering several plant species that have since been named in his honour. In 1913, he moved from Ontario to Alberta and for some years thereafter he operated a farm near Edmonton.

By 1920 , Dr. McCalla was widely recognized as an authority on the flora of our region, for in that year his fine book "Wild Flowers of Western Canada" appeared. He was an instructor at the Edmonton Normal School for two years before being transferred to the Calgary Normal School in 1925. He held this position until his retirement in 1938.

Over many years Dr. McCalla studied flora of the Rocky Mountains in the United States as well as in Canada. His excellent herbarium was donated three years ago to the University of Alberta. Dr. McCalla also specialized in photographic work and 25 volumes of his enlarged photographs of flowers and trees have been presented to the National 'Museum of Canada.

In 1956 Dr. McCalla was awarded an honorary degree of Doctor of Laws by the University of Alberta.

He is survived by his widow, four daughters, three sons, 15 grandchildren and 12 great-grandchildren. Five of his childnen were graduated from the University of Alberta.

\section{by Elizabeth Cruickshank, Regina}

All who enjoyed his outstanding flower photographs in the Blue Jay, or valued his friendship, will miss Dr. McCalla.

For his work in botany Dr. McCalla won international recognition. Three years ago he donated his extensive herbarium to the University of Alberta and twenty-five volumes of flower and tree photographs to the National Museum, Ottawa. He derived great satisfaction from the knowledge that, though he missed his collections, they were in a safe place where they would be used. Gratifying indeed for him to feel the work of a long life of enthusiastic effort and patient study was appreciated. These gifts, along with his delightful book on prairie wild flowers published in 1920 and the plant pictures which were a regular feature of the Blue Jay. for a number of years, are tangible monuments to him. They will enrich the experience of botany students who follow him.

But Dr. McCalla's greatest gift, the kind of intangible gift that is eternal, was of a life well lived by a dedicated man of great wisdom, yet so warmly human and humble. His faith, like the tendrils of the wild morning glory he wrote so feelingly about, reached out to inspire and strengthen all those with whom he came in contact.

From those whose lives his friendship enriched, and from Blue Jay readers, comes this expression of sincere sympathy to Mrs. McCalla and family in their sad loss of husband and father. 


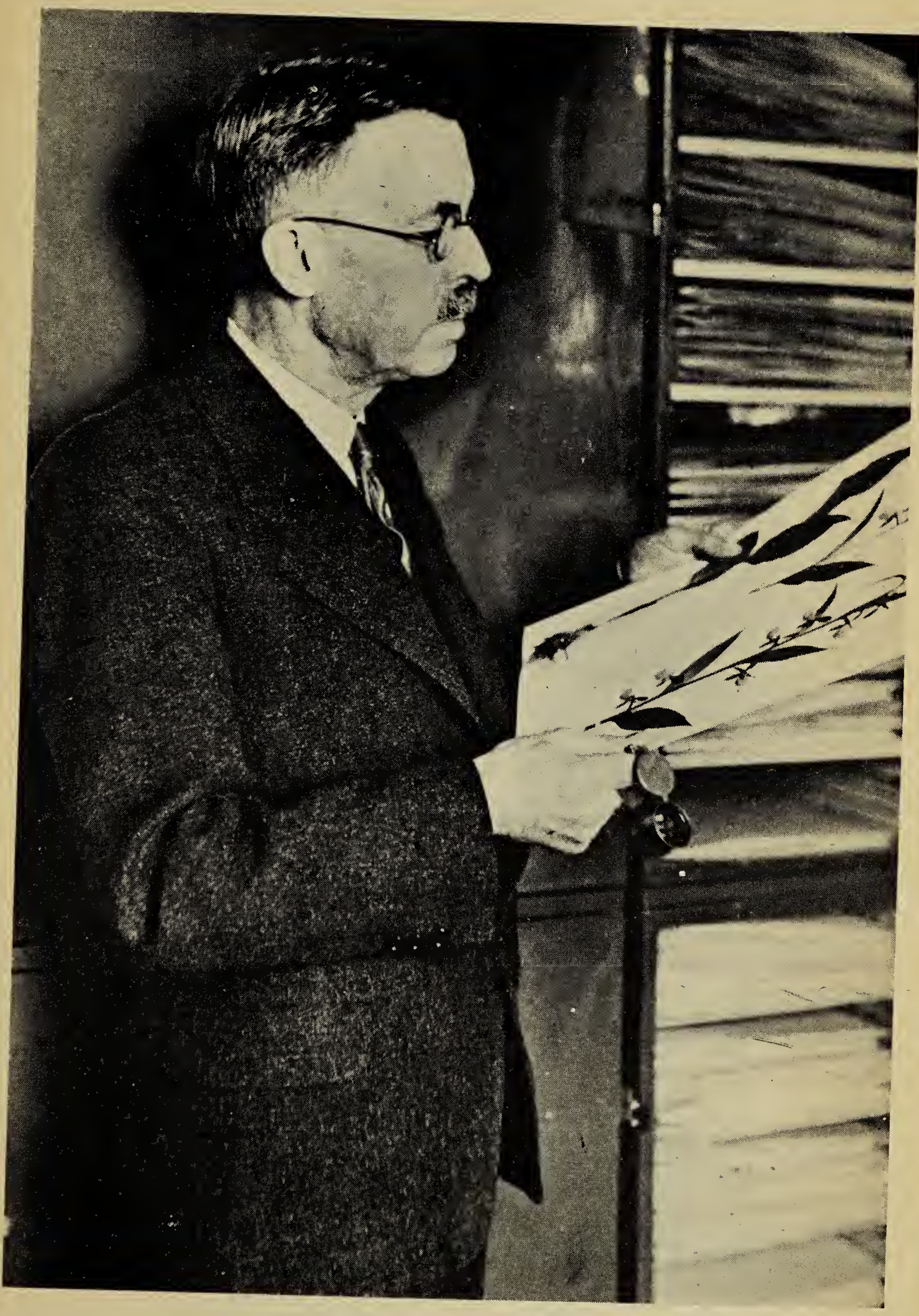

Dr. W. C. McCalla in his herborium at home, Calgary. 